\title{
The Effect of Kuwaiti Online Readers' Comments on Sectarian and Tribal Issues: A Case Study of the Online Newspaper Alaan
} Ali Dashti

Mass Communications Department, Gulf University for Science and Technology, P.O. Box 527, Salmiyah 22006, Kuwait

\begin{abstract}
One of the dilemmas faced by online newspapers is how to handle readers' comments. The interactive nature of the Internet encourages online readers to express their ideas, feelings and opinions freely without fear of negative outcomes resulting from crossing the restrictions of freedom expression that have been set by the government or by online editors. Arab online editors encourage their readers to comment on news stories but censor what they consider to be offensive, anti-nationalist or blasphemous against Islam. An attitudinal study involving online content analysis found those readers' comments in the first Kuwaiti online newspaper, Alaan, encourage enmity among its readers and lead to increased religious and ethnic bigotry among Kuwaiti students.
\end{abstract}

Keywords: Online comments; Censorship; Students; Online newspaper; Kuwaiti online newspaper; Sectarianism; Tribalism and public sphere

\section{Introduction}

One of the benefits of online journalism has been the enhancement of freedom of expression among the Arab online population [1,2]. Many Arab countries have a long and rich history of practicing censorship of traditional mass media [3]. However, the technological developments of the 1990s helped to establish new media that have begun to change the landscape of the relationship between the government and the media, especially in cyberspace. Although most Arab governments have attempted to impose local rules and regulations as a means to control the Internet [4], their attempts to directly suppress the freedom of expression have not been successful. As a result, online journalism has become a public sphere where ideas, thoughts and feelings can be expressed freely. This trend toward freedom can be seen in online readers' comments on articles, news, opinion pieces and columns published online.

This new element of online interactivity has forced many, if not all, local newspapers to create online versions of print newspapers or establish online-only newspapers. For example, in 2001, Elaph (www.elaph.com) became the first Arabic online newspaper based in London; this newspaper publishes articles from freelance journalists and columnists from most Arab countries who write freely without government censorship and provides a free space for readers to comment on any posted issue. In June 2007, Alaan (http://www.Alaan. cc) became the first and most read Kuwaiti online-only newspaper to provide 24 hours of continuous news. Today, there are more than 10 online Kuwaiti newspapers ${ }^{1}$.

One of the features of online journalism is readers' comments. Most online newspapers, including local newspapers, allow online readers to comment on their columns or articles in accordance with the newspaper's rules and regulations. This feature has created a two-way communication between the senders (newspapers) and the receivers (online readers). However, this new avenue of communication has raised many conflicts in issues concerning freedom $v s$. national security, freedom $v s$. local constitution, freedom vs. culture, freedom vs. ethics and freedom vs. nationalism. The Kuwaiti government recently

${ }^{1}$ All local Kuwaiti print newspapers also have online versions.

${ }^{2}$ http://www.alaan.cc/client/pagedetails. asp? nid=7658 \& cid=30.

${ }^{3}$ By law, it is illegal to criticize the Emir. stepped in to manage online publication through new online media regulation [5]. This action has led to contrasting views regarding online censorship. Supporters of the regulations claim that online comments are offensive divide Kuwait's national unity and in cite hatred among its citizens, whereas opponents dismiss these claims and accuse the government of using such justifications to retain the control over freedom in cyberspace that it has exerted over traditional print media.

To avoid being banned, Alaan set new rules disallowing readers' comments that are blasphemous against Islam, insult the Emir or employ any provocative or shameful statements in violation of the Kuwaiti constitution [6]. Islamist members of the Kuwaiti Parliament also are pressuring the government to block YouTube and other Internet sites that blaspheme Islam [7], and the Ministry of Information is seriously considering monitoring online publications [8]. In 2008, the publisher of Alaan, Mr. Saad Bin Taflah Al-Ajmi, was indicted in court for publishing online articles that appeared to violate the press law of 2006. However, the case was dismissed because electronic publications were not covered under the 2006 press law and because the newspaper's servers were physically located in the U.S. ${ }^{2}$ On August 19, 2007, a local journalist who manages an online magazine and forum (Alommah.org) was arrested by the secret service in response to a comment made on his forum criticizing the Emir, and in 2010, a Kuwaiti Internet user was also arrested for a comment he made online regarding the Kuwaiti Emir $^{3}$. This scenario was repeated in 2011 with the arrest of several Twitter users for comments the government claimed to be harmful to national unity and Kuwait's relations with neighboring countries. Kuwaitis have been arrested with increasing frequency for comments they posted online, especially on social networking sites.

Young Arab journalists, media observers and activists in the field

*Corresponding author: Ali Dashti, Assistant Professor, Mass Communications Department, Gulf University for Science and Technology, P.O. Box-527, Salmiyah 22006, Kuwait, Tel: +965-2530-7095; E-mail: dashti.a@gust.edu.kw

Received December 05, 2012; Accepted February 22, 2013; Published March 01,2013

Citation: Dashti A (2013) The Effect of Kuwaiti Online Readers' Comments on Sectarian and Tribal Issues: A Case Study of the Online Newspaper Alaan. J Mass Communicat Journalism 3: 148. doi:10.4172/2165-7912.1000148

Copyright: (c) 2013 Dashti A. This is an open-access article distributed under the terms of the Creative Commons Attribution License, which permits unrestricted use, distribution, and reproduction in any medium, provided the original author and source are credited. 
of online journalism support the notion that online newspapers give young people an alternative space in which to share their political and social views and discuss sensitive issues that are banned in local traditional media [9]. Online news has enabled greater interactivity than print newspapers [10]. The public's tendencies and willingness to post information to cyberspace and/or to express their ideas in this domain seem to illustrate the growing discontent with the lack of freedom of expression in the local press. Few studies have focused on online readers' comments [11]. The present paper aims to study the effect of online readers' comments on Kuwaiti society and to determine whether online comments are used properly to share ideas freely and promote freedom among the population or whether they negatively affect national unity in Kuwait, causing religious hatred among online users and encouraging sectarianism and tribalism. The negative outcomes of online comments may encourage the government to establish new law to regulate online comments.

\section{Online comments}

One of the greatest features of online journalism is the publication of news that local media may miss or conceal and that online stories provide links to other sites to encourage in-depth discussions and comments [12], giving readers the opportunity to express their opinions regarding different political issues and merging traditional media and new media [11].

The interactive nature of the Internet is a primary characteristic that encourages freedom of expression. Interactivity is the relationship between the end-user(s) and the gatekeeper(s) that maintain(s) the means of communication; to be active means to be able to express, participate, gather, and process information. Interactivity gives the user the opportunity not only to receive information but also to comment, share and disseminate it [13]. Online interpersonal interactivity, such as readers posting comments on online news sites, especially unfiltered comments, have changed readers' perspectives on public opinion, media influence and their own personal opinions; thus, readers' comments on online news sites and the associated user-touser interactivity have influenced readers' perceptions of social reality and altered their personal opinions of the issues contributing to social reality [14].

Deuze [15] divides the interactivity of online journalism into three categories: a) navigational interactivity, in which the user navigates through content in a structured way (e.g., back to the top or to the next page); b) functional interactivity, in which the user interacts with other users and news outlets through discussion, comments and e-mail; and c) adaptive interactivity, in which the user customizes the site's content to reflect his or her preferences.

In his study concerning the readers' comments of $\mathrm{Al}$ Jazeera website, found that $\mathrm{Al}$ Jazeera's readers were actively participating in the news making process through their comments. However, handling readers' comments is the most controversial issue many online newspaper's editors are facing today because of the controversial nature of establishing a balance between readers' participation and standards of decency, fairness and accountability [16]. Several American online newspapers block readers' comments that violate rules concerning personal attacks, racist language or insensitive comments [17].

Readers' anonymity is another problem confronted by online news staff; many newspapers are seriously considering giving greater prominence to commenter's using real names, requiring registration before posting comments or ranking comments according to their credibility and trust worthiness [18]. Some scholars have raised concerns regarding the ethical use of anonymous names and comments that are un truthful or unprofessional [19], which encourage incivility and damage trust [20]. Controversial issues motivate online news readers to post hundreds of messages in a short time that carry racist, stereotypical or incorrect information because most online news sites do not require commenter's to post under their real names [21]. Readers' comments can affect social reality by shaping readers' perceptions or altering readers' opinions [22]. Comments can have this effect regardless of Arab governments' attempts to monitor and regulate online comments. For example, in his study of content published on Al-Arabiya's site during the Iraq War, [23] found that Arab readers, in addition to criticizing the content of Al-Arabia and offering their own perspectives or providing eyewitness accounts, caused other readers to change their opinions about specific topics and shaped public perception of particular issues.

To prevent their readers from moving to another media outlet, most online newspapers have added a section for comments with a higher level of freedom of expression than is found in print publications. However, this increased level of freedom has not prevented criticism from other online or offline readers, especially of comments related to religion, obscenity, nationalism or racism. Similar to print media, most online newspapers state that comments reflect the authors' opinions, not the newspaper's, to prevent potential legal action. All Kuwaiti online newspapers publish this legal statement except for Alaan, which further states that it will not publish any comments that blaspheme Islam or any religion, insult the Emir, or are hateful, in accordance with the Kuwaiti Constitution [24]. Alaan's commenting policy is as follows:

The editors at Alaan work day and night dealing with readers' comments. Most readers adhere to the newspaper's comments policy... there are a few who believe that accusations and provocative or shameful statements are part of free expression, which we absolutely reject...Alaan opened the space for online readers to comment on any news or articles, creating two-way communication between the producer of news and receivers, creating new social interaction with the writers that never existed before [25].

Alaan also received negative reactions from other Kuwaiti online newspapers, such as Zoom, which accused Alaan of being a medium for anti-nationalism by dividing the Kuwaitis and creating hatred among them in response to the comments made on Alaan's site [26]. Alaan became a target for hackers' attacks [25]. After one week of allowing online comments, Alaan removed all readers' comments but retained the articles in its archive.

\section{Content analysis}

Researchers use content analysis to acquire detailed information about their study subjects [27] defines content analysis as:

A technique for the systematic, quantitative and objective description of media texts, that is useful for certain purposes of classifying output, looking for effects and making comparisons between media and over time or between content and 'reality'.

Consistency, a lack of ambiguous wording and clearly defined coding are important in content analysis to obtain reliable results [28] In recent years, researchers have applied content analysis techniques to online content using standards similar to those used for analyses of print media but with additional elements, including story postings, story layers, and audience behaviors [29]. To overcome challenges 
such as content authenticity, source verification, the accuracy of news reporting, and journalism norms and standards, Christopher [30] describe several methods that researchers should consider in conducting online content analyses, including sampling, unitization, categorization and coding. These authors conclude that online content analysis has several advantages over print analysis, including reducing the cost of data collections, making new sources of data available, introducing new areas of research and helping improve the quality and validity of content analysis. However, these advantages do not exempt online content analysis from the potential for erroneous conclusion so the need to verify the representativeness of the sample population; several elements of the Internet, including rapid growth, rapid change, a broad scope of information, and a chaotic structure, can threaten the external validity of online research [30].

\section{College students}

Researchers use college students in their studies not only because they are pioneers of social change and early adopters but also because they are heavy users of the Internet [31] , and their news consumption behavior is considered important due to the availability and accessibility of news sources $[32,33]$. Students live in social environments that are conducive to news consumption, and they are willing to change their views prior to graduating [34]. Studies have shown that those who begin reading news online at an early age are more likely to become regular users of online news [35]. For years, it has been thought that older adults are the primary consumers of news, but the Internet has changed this notion. With the accessibility of the Internet, young adults read more news than before [36]. During school years, there are different reasons for students to use the Internet, but fulfilling the need to keep up to date is the most important service provided by news media [37].

These concepts were defined and coded for this study, and two research questions were formulated:

Q1: What are students' perceptions regarding the sectarian and the tribal comments in the online newspaper Alaan?

Q2: What is the nature of readers' comments in Alaan regarding sectarian and tribal issues?

\section{Methodology}

This study examines the effect of negative and positive online comments' on Kuwaiti students. With the collapse of Saddam Husain's regime in 2003, the political unrest in Iraq has affected the political and social life of Kuwait [38]. This is noticeable in the public debates in the Kuwaiti National Assembly, the media (print and online) and among civil societies. Two methods are used in the present study: attitudinal tests and web content analysis. The online newspaper Alaan was selected for this study because it was the first Kuwaiti online-only newspaper and is not associated with a local print newspaper. Alaan is the most read online newspaper, and many local columnists have praised it in local print newspapers [23]. Eight controversial articles that involve topics related to sectarianism (Sunni \& Shiite) and tribalism (Bedouins and 'Alhather' urbanites) and readers' comments on these articles were selected for this study. Five of the articles were related to sectarianism and three to tribalism. The names of the authors of the columnists were removed from the selected columns so they would not bias the readers' perceptions. Students were selected from among different college classes at Kuwait University (public) and GUST University (private).

For the attitudinal test, each student was given a five-page questionnaire. The first page included general questions regarding the usage of online newspapers, posting of online comments, gender, age and school year. These questions were answered before each student read the selected article. Then each student was asked to read one article and its comments. After reading all the comments of the selected article, each student was asked to answer the perception questions in the last page according to Likert scale. SPSS software was used to collect and analyze the data.

Web content analysis for the articles was performed using the attitudinal test to determine how often sectarian and tribal terms were used in the readers' comments. Content analysis is important for this study because a systematic and replicable process [39] is required to obtain accurate results.

Unit of Analysis: Alaan readers' comments.

Coding: Words or phrases depicting sectarianism or tribalism ${ }^{4}$.

\section{Results and Discussion}

For this study, there were 359 participating students (84 male and 274 female). A total of 161 students read sectarian articles, whereas 198 read tribal articles. There was a disparity in the numbers of participating male and female students. Because female students constitute almost two-thirds of students in public and private universities in Kuwait. To ensure that gender disparity did not affect the results, a Levene's test for equality of variances was conducted between the two genders, and the results show no significant differences in their answers, with a low of .002 and a high of .465 level of significance. Among participating students, 63 percent were aged 18 to $20,32.3$ percent were aged from 21 to 23 and 4.5 percent from 24 to 27 .

One hundred eighty-two (51\%) of the participating students read electronic newspapers, where as176 (49\%) do not. Despite the fact that half of the sample does not read online newspapers, the results indicate that there is a trend among young adults to utilize new Internet technology and smart phones. The 49 percent who do not read online newspapers might still read print newspapers or receive news from other media sources, such as smart phones and TV broadcasts. This might explain why only 18 percent $(n=64)$ read the online newspaper Alaan, whereas 82 percent $(n=294)$ do not. When students were asked whether they read the comments of news and articles published online, 45 percent $(\mathrm{n}=160)$ said they do read the readers' comments, whereas 55.2 percent $(n=198)$ said they do not. Although, 55.2 percent reported that they do not read the online comments, the remaining percentage (45\%)shows that many users read the comments, as it is considered to be a forum for express opinions and views freely.

A high percentage of students $(73 \% n=263)$ read all or most online comments even if the comments are not related to the main subject of the article. One explanation for this is that students are interested in reading online comments because they reflect the commentators' religious, political and social backgrounds. Only 26 percent $(n=93)$ of the students do not read the comments if they are not related to the main subject of the article.

When students were asked whether they comment on news and

${ }^{4}$ Country names or other vocabulary used in readers' sectarian comments have different meanings when used locally; for example, Iran means Shiite, Saudi Arabia means Wahabi, Turbans means Shiite religious people, Majos (Magus) means Shiites who came from Iran, Safawi (Safavids) means Shiites with Iranian origins, Talaban means Sunni radicals, and infiltrators refers to both Sunni and Shiite. A the same time, some vocabulary may sound normal but is meant to have negative sectarian meanings. 
articles online, 48 percent $(\mathrm{n}=173)$ said they do not comment, whereas $24.5(n=88)$ percent rarely comment, 23.1 percent $(n=83)$ sometimes comment, 2.8 percent $(\mathrm{n}=10)$ often comment, and only 0.6 percent $(n=2)$ always comment. With regard to the question of whether the students read the online tribal or sectarian articles, the results indicate that 58 percent read sectarian news compared to 51 percent who read tribal news. Similarly, 42 percent do not read sectarian news, whereas 49 percent do not read tribal news (Table 1).

Seventy-one percent $(n=253)$ of the participating students said they do not post their real name when commenting online, whereas 29 percent $(\mathrm{n}=103)$ said they do post their real name. This finding supports the notion that anonymity encourages readers to comment on news freely without the fear of being identified and exposed socially or politically.

With regard to research Q1 regarding the sectarian and the tribal comments, 44 percent $(n=61)$ of the respondents disagree or strongly disagree that readers' comments on sectarian news or issues are not connected to the content of the article, whereas 49 percent $(n=80)$ disagree or strongly disagree that comments are not connected to the content of the tribal news or issues. At the same time, 39 percent $(n=55)$ agree or strongly agree that the comments on sectarian news and issues are not connected to the content of the article, and 40 percent $(n=64)$ agree or strongly agree that the tribal comments are not connected to the content of the article. These results indicate that readers are biased and carry prior perceptions regarding issues related to sectarian and tribal issues.

Regardless of the negative connotation of the comments, the majority of the respondents (76 percent $(n=72)$ from sectarians articles and 77 percent $(n=90)$ from tribal articles) believe that readers' comments are part of free speech. This might be because even though the respondents may not be satisfied with the comments made regarding sectarian and tribal issues, they feel that freedom of speech is a value to be respected and protected as part of Kuwaiti constitutional rights in a democratic system. Interestingly, a higher percentage of respondents (46 percent $(n=55)$ from sectarian articles and 51 percent $(n=47)$ from tribal articles) agree with employing legal regulation on readers' comments compared than those who disagree ( 35 percent $(n=42)$ from sectarian articles and 33 percent $(n=31)$ from tribal articles). Although the respondents believe in free speech, due to the important negative consequences of the readers' comments, they believe in the necessity of legal regulations to prevent the abuse of free speech online. This explains why the majority of the respondents $(62$ percent $(n=55)$ from sectarian articles and 52 percent $(n=60)$ from tribal articles) support pre-censorship of readers' comments, where as only 25 percent $(n=24)$ of respondents to sectarian and 30 percent $(n=35)$ of respondents tribal articles disagree (Figures 1 and 2).

The above results regarding regulations and prior censorship are strongly supported by a majority of the respondents who believe that readers' comments on sectarian ( 80 percent $(\mathrm{n}=51))$ and tribal $(79.4$ percent $(\mathrm{n}=81))$ news and issues have a negative effect on Kuwaiti society; similarly, the majority of the respondents ( 77 percent $(n=52)$

\begin{tabular}{|l|l|l|l|l|}
\hline \multicolumn{2}{|l|}{} & Yes & No & Total \\
\hline Sectarian & $\mathrm{n}$ & 93 & 68 & 161 \\
\cline { 2 - 5 } Tribal & $\%$ & 58 & 42 & $100 \%$ \\
\hline & $\mathrm{n}$ & 99 & 97 & 198 \\
\cline { 2 - 4 } & $\%$ & 51 & 49 & $100 \%$ \\
\hline
\end{tabular}

Table 1: The percentages of Students reading sectarian or tribal online news and articles.

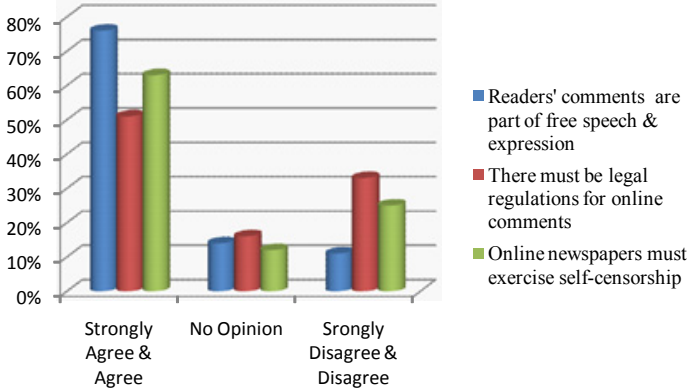

Figure 1: Sectarianism and censorship

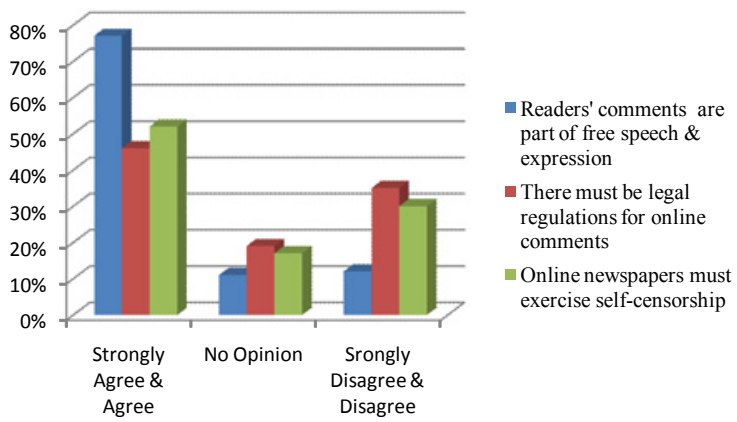

Figure 2: Tribalism and censorship.

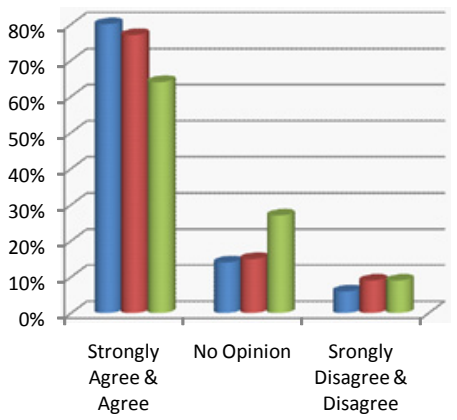

Readers' comment increase Sectarianism Sectarian comments affect national unity

Sectrianism has increased in the society

Figure 3: The effects of sectarian comments.

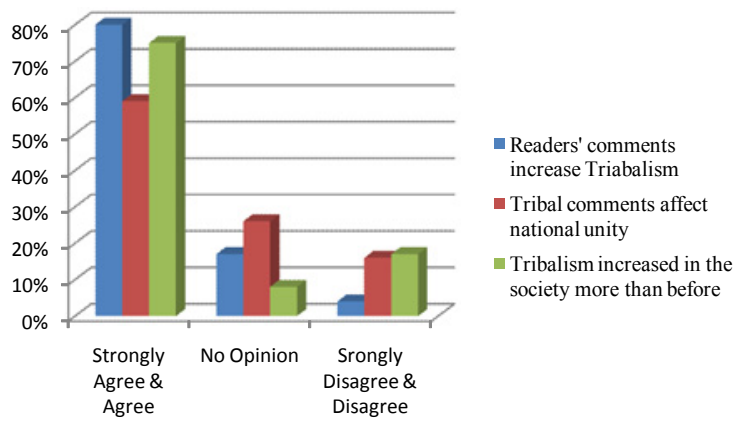

Figure 4: The effects of tribal comments.

from sectarian articles and 59 percent from tribal articles $(n=60))$ are aware of the negative outcomes that these readers' comments have on national unity in Kuwait. As for the respondents, readers' comments reflect the increase in sectarianism and tribalism in Kuwaiti society, with 64 percent $(n=29)$ from sectarian articles and 75 percent $(n=67)$ 
from tribal articles. This result gives an indication of how the readers' comments can negatively affect the sectarian and tribal components of Kuwaiti society (Figures 3 and 4 ).

According to these results, readers' comments not only negatively affect other readers internally but also affect Kuwait relations with other states such as neighboring Gulf States, Arab and non-Arab Middle-Eastern countries and some Western states. There sult shows that 50 percent $(n=107)$ of respondents agree, and only 27 percent $(n=58)$ disagree, that readers' comments have a negative effect on Kuwait international relations.

Concerning research Q2, content analysis for readers' comments on the articles selected for this study shows that Alaan has widened the level of expression, but it continues to regulate some comments by deleting some unsuitable words or phrases. Many of the sectarian comments were intended to be against Shiites through their use of words such as Iranian followers, Safawis, and Majoos (Table 2).

Similarly, strong tribal words and phrases were used to discuss issues related to nationalism. In many cases, the comments were not related to the main points of the articles; instead, they argued about religious issues between the Shiites and the Sunnis that were formerly discussed in online forums in which readers sharply criticize or attack each other without focusing on the subject at hand. Not all of the comments were fully sectarian or tribal, but most comments contained harsh words or statements that might be considered offensive to other religious sects or tribes. Iran and the Kingdom of Saudi Arabia were the most sensitive sectarian terms the readers indirectly used to make fun of or insult other religions in which Iran represents the Shiite and Saudi Arabia represents Sunni Wahabi. The general tone of the comments may cause the readers to become very offended or angry, especially when the comments move away from the main topic. In some cases, comments form into two sectarian groups, and readers associate themselves with one of the groups. However, there were neutral comments criticizing both groups. Some comments encouraged the newspaper to censor other readers' comments, and others complained about their comments not being published. Alaan only allows 500 characters for each comment.

\section{Conclusion}

Online comments have opened a path for new ways of practicing free speech, but this has not come without negative consequences. Readers' comments put online newspapers' editors in an awkward position of balancing free expression and censorship. Editors want audiences to read and participate in their newspapers through sharing opinions, ideas and views, but they do not want to be a tool of hatred, discrimination, rudeness, blasphemy, or increased sectarianism in their society. Censoring readers' comments will turn online readers away, and using self-censorship or regulations will give governments a reason to practice control over online materials by justifying their actions in the name of preventing anti-nationalism, sectarianism, or blasphemy.

Readers' comments continue to cause concern to the online newspaper Alaan. Periodically, Alaan notifies its readers of the publication's readers' comments policy. An article posted in Alaan (23/8/2011) claimed the newspaper opened the window to the expression of freedom regardless of legal actions they may face in order to protect readers' privacy; the thousands of comments they receive daily forced them to assign dedicated people to moderate comments in accordance with four prohibited areas: religion, the Emir's integrity self-identity, provocative or shameful statements causing hatred and straying from the main point of the article. However, because of the readers' reluctance to adhere to the newspaper's regulations, the editors of Alaan wrote the following [40].

Accordingly, we, as of today, will disregard any comments contrary to the four parameters mentioned above without referencing to themas usual, noting that this method is followed by all newspapers and websites, both Arab and foreign. Thus, such a new policy tends to accelerate the dissemination of comments and freedom of opinion. Our policy gives the readers the chance to appeal against unfair with holding of their comments by writing to the editor...

Regardless of Alaan's recent statement regarding readers' comments, we found many comments containing words or phrases that could be offensive on either sectarian or tribal grounds. For example, the following story appeared in Alaan [41].

The security of Bahrain Interior Minister returned the situation in the City Center shopping mall to normal after arresting group of subversives of both genders who created chaos and intimidated the shoppers, according to Bahrain News Agency. According to the

\begin{tabular}{|c|c|c|c|c|c|}
\hline \multicolumn{4}{|c|}{ Words Associates with Sectarianism* } & \multicolumn{2}{|c|}{ Words Associates with Tribalism** } \\
\hline & Used & & Used & & Used \\
\hline Shiite & 12 & Shiite Supreme Clerics & 1 & Bedouin(Nomads) & 2 \\
\hline Sunna & 13 & Rawafith (Shiite) & & Alhather (Urbans) & 1 \\
\hline Majus (Magus) & 3 & Athnab (betrayers) & 3 & Ruwaybithah (Ignorant) & 1 \\
\hline \multirow[t]{2}{*}{ Mullas (Clerics) } & \multirow[t]{2}{*}{5} & \multirow[t]{2}{*}{ Tasfeer (Deportation) } & & Taratheeth & \\
\hline & & & & Murtaziqa (Missionaries) & \\
\hline Safavids & 9 & Slaves of Iran & & Muzdawajeen (Dual Nationality & 6 \\
\hline Sectarian & 13 & Turbans (Shiite) & 3 & Baysari (Low-class citizens) & \\
\hline \multirow[t]{2}{*}{ Alfurs (Persians) } & \multirow[t]{2}{*}{21} & \multirow{2}{*}{$\begin{array}{l}\text { Insulting Prophet Mohammad's } \\
\text { Companions }\end{array}$} & \multirow[t]{2}{*}{1} & Blueblood (Elites) & 1 \\
\hline & & & & Non-Kuwaiti & 1 \\
\hline Wahhabis & & Altaqiyah (Shiite) & 1 & Natives & 1 \\
\hline Talabani & & Hussayniat (Shiite) & & Inner areas & \\
\hline Khomeinism & & Loyal to Iran & 3 & Outer areas & \\
\hline Shiite Crescent & 1 & Iranian origins & & Wild Batinah (High Class) & 1 \\
\hline Jafari (Shiite) & & Iranians & 6 & Sub-elections & 1 \\
\hline Hypocrites & 11 & & & AbeedAlbasrah (Iraqi Origin) & 1 \\
\hline
\end{tabular}

*From the five sectarian articles used in the study

${ }^{* *}$ From the three tribal articles used in the study 


\section{Words or phrases used}

Shiites are of Iranian origin, and their loyalty is to Iran; that's why we should be careful with them unless their loyalty to Kuwait and its people is proven to be evident and clear, but what we see is the contrary, they walk in the path of Iran. Dual citizens used five times in one article

Safavids

Iranian betrayers (Athnab Iran), Iranian agent, Iranian followers

My Kuwaiti Shiite brother what you own of money and freedom of expression are under the umbrella of the Sunni governance

Table 3: Phrases posted after the release of Alaan's code of ethics.

Interior Minister, legal action is being taken against those vandals who rioted and sabotaged the place.

The story, which was released by the Bahraini official news agency, never mentioned who was behind the incident or their motives. In spite of this, the readers' comments included terms such as Iranian agenda, followers of Iran, Iran's invasion of Bahrain, this action was intended to hide Syrians' atrocities, and terrorist; most, if not all, of the comments were biased and indicated subjective perceptions. Table 3 presents some words and phrases posted on Alaan:

On the $4^{\text {th }}$ of October, 2011, Alaan published an article [42] that was considered by many readers as anti-tribal. One hundred sixty comments were posted, and most of them accused the author of fomenting anti-tribalism in Kuwait. In this article, sectarian and tribal words were used, but the editors of Alaan tried more than 25 times to delete some words that were considered unacceptable for publication. The word "sectarianism" was used more than seven times, and the word "tribalism" was used more than four times. One week later, all the comments were deleted from the site, but the story remains online.

However, the results of this study do illustrate some concerns that need to be seriously addressed. Students showed their dissatisfactions regarding sectarian and tribal comments. It is true that freedom of expression is important, but protecting society from sectarianism and tribalism is more important, as is the country's relationships with other nations. Alaan needs to go beyond expressing their concern and address this problem seriously. This publication needs to act now instead of waiting for the government to take action that will definitely strip freedom from the people.

It is clear that it is not an easy task for the editors of Alaan to keep up with all comments, determine whether to delete them or remove some words, but because Kuwaitis and other online readers in the Gulf feel comments are the best way to express their freedom, the editors of Alaan should be more serious in removing comments that have sectarian or tribal aspects. Alaan should adopt an anti-ethnic rule that most democratic nations use to prevent the provocation of ethnic or tribal groups.

\section{References}

1. Dashti AA (2009) The Role of Online Journalism in Political Disputes in Kuwait. Journal of Arab and Muslim Media Research 2: 91-112.

2. Al-Saggaf $Y$ (2006) The online public sphere in the Arab world: The war in Iraq on the Al Arabiya website. Journal of Computer-Mediated Communication 12.

3. Boyd D (1993) Broadcasting in the Arab World: A Survey of Electronic Media in the Middle East, Ames, lowa, State University Press.

4. Reporters Without Borders (2010) Middle East \& North Africa

5. Saeid A (2010) Govt attempts to censor blogs 'unacceptable', Kuwait Times.

6. Al-Barrak A (2008) Alaan Tanhaj Nahjan Jadidan Wa Sarian Fi Altaamol Maa Alta'eliqat. Alaan.
7. S (2008) Akadimiyoon Wa Muwatinoon LiAlwatan: Matloob Riqabah Ala Mawaqi'e Alinternet Wa Hajb Qahar Lilhoriyat. Alwatan. Kuwait.

8. Al-Dosiri K (2008) Ale'elam: Nofakir Jadiyan fi Tantheem Alnashir Alelectoron wa Haliyan La Natahamal Masooliyat ma Yonshar Fi Alinternet. Aljarida. Kuwait.

9. Salahat M (2007) Alsahafah Al-Electronia Masaha Hurra Lilshabab, Elaph.

10. Stovall JG (2004) Web journalism: Practice and promise of a new medium, Boston, MA, Allyn \& Bacon.

11. Abdul-Mageed M (2008) Online News Sites and Journalism 2.0: Reader Comments on Al Jazeera Arabic. tripleC 6: 59-76.

12. Hachten WA (2005) The Troubles of Journalism, New Jersey, Lawrence Erlbaum Associates, Inc.

13. Kopper GG, Kolthoff A, Czepeka A (2000) Research Review: Online Journalism. Journalism Studies 1: 499-512.

14. Lee EJ (2010a) What Do Others' Reactions to News on Internet Portal Sites Tell Us? Effects of Presentation Format and Readers' Need for Cognition on Reality Perception. Communication Research 37: 825-846.

15. Deuze M (2003) The web and its journalism: considering the consequences of different types of newsmedia online. New Media \& Society 5: 203-230.

16. CBC News (2009) Online readers' comments raise prickly issues for publications, CBC NEWS.

17. Nielsen C (2010) Community Conversation or 'The New Bathroom Wall?' Anonymous Online Comments and the Journalist's Role. Annual Meeting of the Association for Education in Journalism and Mass Communication. Denver Colorado.

18. Perez-Pena R (2010) News Sites Rethink Anonymous Online Comments. The New York Times.

19. Hlavach L, Freivogel WH (2011) Ethical Implications of Anonymous Comments Posted to Online News Stories. Journal of Mass Media Ethics 26: 21-37.

20. Heim K (2008) Fair Comment? The Ethics of Anonymous Postings on News Web Sites. Annual Meeting of the Association for Education in Journalism and Mass Communication. Chicago, IL.

21. Post T (2007) Newspapers struggle with online comments. Minnesota Public Radio.

22. Lee EJ (2010) Effects of readers comments on Internet news sites on construction of social reality: The moderating role of need for orientation. International Communication Association annual conference. Singapore.

23. Al-Abdali S (2006) Ghdan Yabda'e Alyoom. Raialaam. Kuwait.

24. Al-Barrak A (2010) Taeliqat Shatabnaha, Alaan.

25. Alaan (2010) Adaat Alaan Wa Dawman, Alaan.

26. Zoomkw.com. (2010) Alaan \& alfitnah.

27. McQuail D (2005) McQuail's Mass Communication Theory, London, SAGE Publications.

28. Weber RP (1990) Basic Content Analysis, Newbury Park, CA, Sage Publications, Inc.

29. McLellan M, Porter T (2007) News, Improved: How America's Newsrooms Are Learning to Change Washington, DC, CQ Press.

30. Weare C, Lin WY (2000) Content Analysis of the World Wide Web. Social Science Computer Review 18: 272-292.

31. Jones S (2002) The Internet goes to college: How students are living in the future with today's technology. Pew Internet and American Life.

32. Diddi A, LaRose R (2006) Getting Hooked on News: Uses and Gratifications and the Formation of News Habits Among College Students in an Internet Environment. Journal of Broadcasting \& Electronic Media 50: 193-210.

33. Obaidi JA, Lamb-Williams C, Mordas V (2004) The king of all mediums: A field study of college students use of mediums for news. International Journal of Instructional Media 31: 239-256.

34. Henke LL (1985) Perceptions and Use of News Media by College Students Journal of Broadcasting \& Electronic Media 29: 431-436. 
Citation: Dashti A (2013) The Effect of Kuwaiti Online Readers' Comments on Sectarian and Tribal Issues: A Case Study of the Online Newspaper Alaan. J Mass Communicat Journalism 3: 148. doi:10.4172/2165-7912.1000148

Page 7 of 7

35. Huang JS (2005) Diffusion Theory in an Internet Environment: Testing Four Key Components. The 6th International Symposium on Online Journalism. Austin, TX.

36. Hartman JK (2003) Solving Some Mysteries About the Habits of the Young. Nieman Reports 57: 14-17.

37. Vincent RC, Basil M (1997) College Students' News Gratifications, Media Use, and Current Events Knowledge. Journal of Broadcasting \& Electronic Media 41: 380-392.
38. Wehrey F, Dassa D, Watkins KJ, Martini J, Guffey RA (2010) The Iraq Effect: The Middle East After the Iraq War. Santa Monica,CA, RAND Corporation.

39. Stemler S (2001) An Overview of Content Analysis, Practical Assessment Research \& Evaluation 7: 17

40. Alaan (23/8/2011) Nahj Mutajadid LiAlaan Biltaamul Maa Altaeliqat.

41. Alaan (23/9/2011) Mukhariboon Eqtahamoo 'City Center Bahrain.

42. Al-Duaij A (3/10/2011) Juwaihilyoo Almuaratha Aljadidah, Alaan. 